\title{
Pierre Laforgue, «"Jeter sur la scène un personnage romanesque": les avatars de Vautrin»
}

\section{Marie-Claude Cedrini-Henriot}

\section{(2) OpenEdition}

1 Journals

\section{Édition électronique}

URL : https://journals.openedition.org/studifrancesi/40933

DOI : 10.4000/studifrancesi.40933

ISSN : 2421-5856

Éditeur

Rosenberg \& Sellier

\section{Édition imprimée}

Date de publication : 1 juillet 2004

Pagination : 210

ISSN : 0039-2944

\section{Référence électronique}

Marie-Claude Cedrini-Henriot, «Pierre Laforgue, «"Jeter sur la scène un personnage romanesque": les avatars de Vautrin» », Studi Francesi [En ligne], 142 (XLVIII | I) | 2004, mis en ligne le 30 novembre 2015, consulté le 09 septembre 2021. URL : http://journals.openedition.org/studifrancesi/40933; DOI :

https://doi.org/10.4000/studifrancesi.40933

Ce document a été généré automatiquement le 9 septembre 2021.

\section{(c) $($ ) $\odot$}

Studi Francesi è distribuita con Licenza Creative Commons Attribuzione - Non commerciale - Non opere derivate 4.0 Internazionale. 


\title{
Pierre Laforgue, «"Jeter sur la scène un personnage romanesque": les avatars de Vautrin»
}

\author{
Marie-Claude Cedrini-Henriot
}

\section{RÉFÉRENCE}

PIERRE LAFORGUE, «"Jeter sur la scène un personnage romanesque": les avatars de Vautrin», in La Tentation théâtrale des romanciers, «Question de littérature», Paris, Sedes, 2002, pp.11-17.

1 La Tentation théâtrale des romanciers, actes d'un colloque comparatiste tenu à Tours en 2001, s'intéresse aux tentatives théâtrales des romanciers européens des XIX ${ }^{e}$ et XX ${ }^{e}$ siècles - Flaubert, Zola, Dostoïevsky, Proust, notamment. Parmi les divers articles, celui de Pierre Laforgue, consacré à Vautrin, s'interroge sur la théâtralisation du personnage romanesque, et de ce fait sur la capacité balzacienne à créer pour le théâtre. Après un résumé bref et simplificateur de l'intrigue, il en pose la complexité comme une théâtralité qui tourne à vide, résultant d'une incapacité à entretenir l'illusion théâtrale. Pourtant les multiples costumes du personnage éponyme et la rencontre de deux catégories de personnages issus d'univers génériques fort distincts créent des effets de théâtralité, liés au choc entre comédie de moeurs et roman. Balzac aurait alors créé un personnage qui simultanément engendre et empêche la théâtralité. Pierre Laforgue étudie ensuite le rapport de la pièce aux romans en chantier: Vautrin s'avère au cœur de l'écriture d'Illusions perdues et de Splendeurs et misères des courtisanes; il en conclut que le passage par le théâtre était nécessaire pour que le personnage romanesque atteigne à sa plénitude. 